\title{
Outsourcing education services in South Korea, England and Hong Kong: a discursive institutionalist analysis
}

\author{
Agnieszka Bates ${ }^{\mathrm{a}}$ and Tae-Hee $\mathrm{Choi}^{\mathrm{b}}$ and Yong $\mathrm{Kim}^{\mathrm{c}}$ \\ ${ }^{a}$ School of Education and Lifelong Learning, University of East Anglia (UEA), \\ Norwich, United Kingdom; \\ ${ }^{b}$ Department of Education Policy and Leadership, Education University of Hong Kong, \\ Hong Kong, China; \\ ${ }^{c}$ Department of Primary Education, Cheongju National University of Education, \\ Cheongju, South Korea
}

\begin{abstract}
The outsourcing of education services has been widely adopted across international contexts as a 'tested solution' or panacea to meet various educational problems including school management, curriculum design, teaching and student discipline. Contracting third party providers, it is argued, enhances organisational goals such as efficiency, quality and school improvement. However, the outsourcing of education services has also impacted on established notions concerning the boundaries around teachers' work. This paper deploys the framework of discursive institutionalism to offer insight into how the idea of outsourcing has been activated and circulated by discursive communities in three diverse international settings. Despite its problem-solution logic, the institutionalisation of outsourcing creates its own problems, not least the undermining of teacher professionalism, the 'businessification' of schools and a diminishing of their educational mission.
\end{abstract}

Keywords: outsourcing; discursive institutionalism; education reform; NPM; teacher professionalism 


\section{Introduction}

Despite concerns about service quality and financial irregularities involving private companies managing public schools in the USA (Hursh 2016; Ravitch 2014), outsourcebased education reform continues to migrate across the globe. ${ }^{[1]}$ Ideas such as 'innovation', 'excellence' and 'sustainability' are discursively linked to alternative models for public service delivery, offered by private sector and voluntary organisations under the auspices of New Public Management (NPM) (Hood 1995; Lane 2000; Norris and Kushner 2007). Outsourcing has been framed in these discourses within a problemsolution logic, as a cost-effective solution to a range of educational problems in diverse international contexts. As illustrated by three examples analysed in this paper, these problems range from the perceived inability of teachers to cope with the rise of school bullying in South Korea to the need to inject 'self-improvement' into the entire education system in England and excessive teacher workload in Hong Kong. Outsourcing has been offered as a solution to these diverse problems on the grounds of efficiency, cost cutting, quality and improvement.

The origins of outsourcing can be traced to the beginnings of global competition for US-manufactured products in the 1970s and the need of US companies to cut production costs to remain competitive (Cuban 2012). This rationale led to the relocation of product design and manufacture to Latin American and Asian countries where labour costs were lower. In the 1980 s, a similar cost-cutting idea spread to education and 'contracting out' ('outsourcing') student lunches, bus transport and janitorial services 'rippled across the nation's 14,000 school districts' (Cuban 2012). A decade later, forprofit companies started taking over failing public and charter schools, leading to the rise of EMOs (Educational Management Organisations), management companies involved in 
managing whole school operation, from school dinners to teaching and learning (Cuban 2012; Hursh 2017; Ravitch 2014). As the search for solutions to educational problems continues, EMOs sell their services transnationally to governments seeking to reform their education systems. In Liberia for example, the entire primary education system was outsourced to a US-based for-profit provider of low-cost education, Bridge International Academies and seven smaller operators (Pilling 2017). Outsourcing has thus become a 'travelling idea', i.e. an idea that is 'rhetorically produced', 'appropriated and re-worked in specific, local situations' in different countries as 'hotspots of change' (Ellis et al. 2016, $61)$.

However, empirical studies on the effects of outsourcing have raised a number of concerns ranging from the loss of control over the management of outsourced services and inconsistency in the quality of service to the displacement of employees and loss of collegial workplace relations (Adams et al. 2004). Outsourcing often aggravates problems already existing in the system, for example issues of equity and quality of outsourced provision (Choi 2018; Rivera 2018). The long-term effects of outsourcing include an increase in costs because of the 'profit factors intrinsic within private enterprises' (Wekullo 2017, 453; Williams 2012). Research on 'contracting out' educational provision in the USA points to a growing involvement of corporate organisations that extends beyond localised operations to influence the education policy process itself (Hursh 2017; Rivera 2018). Whilst advocates of outsourcing point to benefits such as a reduction in costs of service and provision of knowledge lacking within the institution (Lambert 2014), critics have reported an escalation of costs and forms of privatised education that are often 'hidden' from parents, local community and other stakeholders (Burch 2009).

As outsource-based reforms continue to travel across the globe, they reconfigure teacher professionalism into a 'form of boundary work' (Seddon et al. 2013, 7) that is 
increasingly affected by the transformation of public education into a global 'edubusiness' (Mahony et al. 2004; Ball 2007). The three examples from South Korea, England and Hong Kong analysed in this paper suggest that outsourcing education services may be at the point of becoming institutionalised, i.e. cast into a system of 'norms, structures, and cultural understandings' that shape organisational behaviour (Khurana 2007: 5). The institutionalisation of outsourcing shifts the traditional boundaries that used to distinguish teachers as professionals from other occupations and non-educational experts. The essential sources of teacher professionalism traditionally included: knowledge of pedagogy and curriculum; responsibility for the 'formation' of young lives; a vocation or 'calling' to a public service (Grace 2014), as well as a degree of autonomy over the conduct of one's work (Seddon et al. 2013). The discursive shift from 'pedagogy' as a holistic process at the heart of teachers' work, to the current term 'teaching and learning' signals a fragmentation of the pedagogical process into the distinctive processes of 'teaching' and 'learning', with 'teaching' sub-divided further into: planning, delivery, examination and quality assurance, and sourced from alternative providers. In changing the established distinctions that determined the principles organising teachers' work, the outsourcing of education services introduces new forces of competition in the 'production, diffusion and institutionalization of alternative ... principles of classification' (Lamont and Molnár 2002, 168). Sociologists working within neo-institutionalist approaches (Powell and DiMaggio 1983; Khurana 2007) observe that, once new organising principles ('institutional logics') become institutionalised, questions about their origins, meaning and purpose disappear from view. 'Institutionalised' and 'institutionalisation' refer here both to the establishment of external rules and structures that give an institution its social legitimacy, as well as to an internalisation of 'institutional logics' by institutional actors. Once outsourcing becomes internalised in this way, it may 
be difficult to challenge, despite 'windows of opportunity' (Kingdon 1984) that open when events emerge to suggest that outsource-based policies may be unable to solve the problems for which they were designed.

While much has been written about how the 'travelling idea' of outsourcing has been changing the boundaries of public-private co-operation in different countries as 'hotspots of change' (Ellis et al. 2016, 61), less is known about the discursive processes that activate and circulate the idea of outsourcing and, over time, institutionalise new forms of professionalism. This paper seeks to contribute to research on 'travelling ideas' by deploying the framework of discursive institutionalism (Schmidt 2010, 2017) to analyse the processes which activate and legitimise the idea of outsourcing to reconfigure teacher professionalism. ${ }^{[2]}$ As teacher educators working in three diverse education systems of South Korea, England and Hong Kong respectively, we have been struck by how outsourcing has been discursively framed as a panacea for a range of radically different educational problems and, importantly, how outsourcing has created its own problems. We use the term 'outsourcing education services' to denote a form of outsourcing observed across the three examples, predicated on financial, legislative and/or structural arrangements for the delivery of teaching and teaching-related work by alternative providers. This paper now turns to the discursive processes that activate and legitimise outsource-based education reform.

\section{Discursive institutionalism as a framework for the analysis of outsource-based}

\section{reform}

To explain the complex dynamics at play in the institutionalisation of outsourcing, we turn to Vivien Schmidt's $(2008,2010,2017)$ theory of discursive institutionalism. Developed in the field of political science, discursive institutionalism is an umbrella term 
for approaches concerned with the substantive content of ideas and the interactive processes of discourse and discursive argumentation in institutional contexts' (Fischer and Gottweis 2012, 19). The key preoccupation of discursive institutionalism is with the ways in which policy discourses shape communicative interactions among political actors as social problems are translated into policies. An analysis of these interactions seeks to shed light on the dynamics of change by identifying the interests, institutions and cultures which engender a 'consensus for change through communication' (Schmidt as cited in Fischer and Gottweis 2012, 16). An analysis of institutionalisation offered by neoinstitutionalist theorists (e.g. Powell and DiMaggio 1983; Khurana 2007) is also important here because institutions such as the market, social hierarchies and professionalism influence both the policymakers and the public. As noted by Fischer and Gottweis (2012), policymakers work by:

structuring or shaping the political and social interpretations of the problems they have to deal with and by limiting the choice of policy solutions that might be implemented. The interests of actors... are influenced by the institutional structures, norms, and rules through which they are pursued... it is often the institutional opportunities and barriers that determine people's preferences, rather than the other way around. (p.17)

Neo-institutionalism thus seeks to explain both the institutional enablers-barriers and the deeply ingrained nature of ideas that have become institutionalised. We return to this issue later, to highlight the dangers of the institutionalisation of outsourcing and its logics of efficiency, cost cutting and competition.

As noted by Schmidt (2017, 247), discursive institutionalism is an important additional element in the 'toolkit' of neo-institutional policy studies that offers explanations of the discursive dynamics of policy change (and continuity). At the heart of these dynamics are ideas and their adoption ('ideational adoption'), dissemination, 
legitimation-contestation and, in some cases, institutionalisation. Ideas have content and process dimensions. The substantive content of ideas is communicated through a range of discourses and supported by rhetorical strategies and other communicative devices (see Table 1). The process dimension consists of discursive interactions that circulate ideas produced by 'ideational leaders' within different discursive communities. Here, Schmidt (2017) makes a distinction between 'coordinative discourse' and 'communicative discourse'. Coordinative discourse involves policymakers and other ideational leaders in policy construction. Communicative discourse is constructed by policymakers and their political agents to make their ideas accessible to the public for discussion, argumentation and contestation.

\section{Table 1 Here}

An important function of discourses is to deploy the persuasive power of ideas, i.e. power through, over and in ideas (Schmidt 2017). Power through ideas rests on actors' capacity to persuade others of the 'cognitive validity and/or normative value of their worldview through the use of ideational elements' (p.252). Power over ideas is the 'capacity of actors to control and dominate the meaning of ideas' (p.252) by monopolising public discourse and action, shaming opponents into conformity or resisting alternative interpretations. Power in ideas is 'found where certain discourses serve to structure thought... or where particular ideas are institutionalised at the expense of others by being embedded in the rules or frames' (p.253).

The process through which agents translate their discourses into actions starts with activating ideas through coordinative discourses within communities of policymakers and experts and then through communicative discourses within the public sphere. As 
noted by Schmidt (2017, 262), some more ambiguous ('polysemic') ideas may be activated as coalition magnets, because their ambiguous nature makes them attractive to groups who have a range of different interests. Ideas that provide common understandings are used as frames of reference to draw groups together as the basis for common action. Ideas that serve as empty signifiers can be interpreted in several different ways and can, therefore, bring diverse groups together in a common cause. Ideas and discourses are often activated by 'rhetorical leaders' who build consensus by exercising power through ideas, i.e. commanding authority through cognitive or normative arguments. Once consensus is reached, the structural power in ideas may be utilised to complete the process of their institutionalisation.

The conceptual tools of discursive institutionalism are crucial to understanding how outsourcing, together with its logics of competition, cost cutting and efficiency, has become a salient feature of 'travelling education reforms' (Seddon et al. 2013). For example, the current cognitive arguments for the outsourcing of public services in England rest on the logic of competition as a driver of efficiency, as in the following example from the 'House of Commons Briefing Paper' on alternative models of service delivery by local government:

The theoretical basis of outsourcing derives from the notion of competition as the driver of efficiency, quality improvement and innovation. The theory is overlaid with practical considerations around cost-cutting in an age of austerity and the need to tackle failings in public services. (Sandford 2016, 11)

The reference to 'failings in public services' above also activates power over ideas: references to failure can be wielded to take control by shaming 'failing schools' into compliance. The power in ideas can be activated in outsource-based reforms to the point where the cognitive arguments for cost-cutting, competition and efficiency begin to be 
used in the normative sense. For example, the idea of 'open public services' has been discursively constructed to mean:

a truly level playing field between the public, private and voluntary sectors... wherever possible, public services should be open to a range of providers competing to offer a better service. (HM Government 2011, 9) [our emphasis]

Whereas under the UK Local Government Act 1972, local authorities were given the power to outsource the provision of public services to private organisations (followed by compulsory competitive tendering introduced with the Local Government Act 1988), the current idea of 'open public services' frames outsourcing in normative terms, as 'truth' and 'fairness' are evoked through the reference to a 'truly level playing field'. Legislation utilises power in ideas to the fullest, by introducing statutory rules as frames of reference to be acted upon and institutionalised, at least in the external, structural sense.

Combined with legislation, such discourses have paved the way for 'multiple privatizations' (Ball 2007), both in the national contexts and within the 'supranational' education policy space (Lingard and Sellar 2013). Outsourcing is part and parcel of the 'competition state', concerned on the one hand with maintaining a competitive advantage in the global economy and, on the other, with its role as "commissioner and monitor of public services... rather than deliverer or even owner and funder' (Ball 2007, 5). Within the supranational policy space, policy solutions are coordinated by organisations such as the OECD, World Bank, World Trade Organisation and UNESCO, global 'edubusinesses' such as Pearson, NGOs and philanthropic trusts (Ball and Junemann 2012). Power over ideas is increasingly activated in education reform through the use of PISA scores ‘as points of reference and forms of legitimation' for national policies (Ball 2012b, 40). 


\section{Methodological approach}

To illustrate the processes of activating and legitimating the idea of outsourcing across international boundaries, we have selected examples from South Korea, England and Hong Kong. The problems encountered in primary and secondary education in these countries arise from the perceived inability of teachers by themselves to cope with the rise of school bullying in South Korea, the need to inject 'self-improvement' into the entire education system in England and unmanageable teacher workload in Hong Kong. Our choice of examining radically different problems in politically, historically and culturally diverse countries aims to bring into sharp relief both the singular logic of outsourcing as a panacea and its concomitant, the undermining of teacher professionalism.

Our choice of discursive institutionalism as an analytical framework is partly a response to Seddon et al.'s (2013, xviii) call for new methods of comparison that would capture the complexity of 'travelling' education reform:

It is not sufficient to state that a reform in one country resembles that of another, but it is important to understand at what level, with what means and, last but not least, for whose benefit and at whose expense convergence occurs.

Discursive institutionalism is one such method of comparison that offers insight into discourse not just as 'content' but also the 'means' through which key actors activate and circulate the idea of outsourcing. To analyse 'content', discursive institutionalism examines data sources such as policy documents, public media reports and other 'texts'. To investigate the 'means', discursive institutionalism traces interactive processes among key discursive players. The interactive aspect of discourse is particularly important 
because it reveals how and why the "carriers of ideas convince others (or not) to take up their ideas' (Schmidt 2008, 7). In the following sections, we deploy the 'toolkit' of discursive institutionalism (see Table 1) to identify the key players, discourses and communicative processes through which the idea of outsourcing has been conveyed and adopted as a solution to radically different problems in South Korea, England and Hong Kong.

\section{Dealing with bullying and 'curtailed' professionalism in South Korea}

The example from South Korea illustrates an erosion of teacher professionalism which arose from government and public discourses undermining teachers' competence in dealing with school bullying. Serious student misbehaviour became a policy priority in Korea in the mid 1990's, in the wake of suicide incidents associated with school bullying. Media reports on 'violence' in schools reaching dangerous proportions amplified the problem to the public, suggesting that the solution could not be left solely to teachers (Dong-A 1995; Hankyoreh 1997). The government responded by taking measures to 'wipe out violence' in schools (Kyunghyang 1997). The mass media also criticised the Ministry of Education (MoE) for its incompetence, calling for 'fundamental' measures at a cross-ministry level (Chung 1996). Despite the established pastoral role of teachers that included emotional support, counselling and behaviour management, public consensus centred around the cognitive argument that, as a crime, school 'violence' had to be urgently eradicated. Counter-discourses that framed bullying as serious misbehaviour rather than 'violence' were also articulated (Kang 2012). However, the cognitive argument about the need to eradicate 'violence', combined with the normative argument about societal values such as student safety and well-being at school, prevailed. Power over ideas was also activated through media discourses questioning teachers' 
competence, with some teachers being accused of concealing 'violence' cases rather than trying to solve them (Chung 1996). This, in turn, led to arguments for co-operation between the 'competent' Ministries, the 'incompetent' MoE and the 'questionable' teachers, no longer seen as the source of expertise required for effectively dealing with bullying at school.

As a result, in 1995 the government announced the first comprehensive measures on school 'violence', involving the Ministries of: Justice; Public Administration and Home Affairs; Culture and Sports, and Information and Communication, in addition to the MoE (MoE 1995). In 2004, the National Assembly passed the School Violence Prevention and Countermeasures Law. The law defined bullying as 'school violence' and prescribed actions to take with offenders and victims. Punitive measures ranged from a referral to social services and special education programs to suspension, class or school transfer, and expulsion from school. Outside experts were to consult the victims and, in some cases, temporary protection, physical and mental treatment were recommended. In 2008, revised legislation strengthened the penalties for perpetrators and increased the involvement of external experts. Besides judges, prosecutors, lawyers and police officers, medical doctors were invited as members of the 'committees on school violence'. School bullies were required to take special education programs with their guardians and to pay the medical bills of the victims.

Ironically, however, the idea of school 'violence' activated and circulated by government ministers, the media and the public, and eventually institutionalised through the above legislation, can be traced back to semantic ambiguity. Unlike in many Western countries and Japan which have unique terms for various acts of 'violence' as distinct from 'bullying' (Japanese Ijime - いじめ), there is no term for bullying (Ijime) in the Korean language. As a result, the term of 'Pokryok (폭력)', which denotes a type of 
'criminal violence', has been used in debates about 'bullying' in schools. Because Pokryok denotes a crime, there was consensus amongst the policy community (politicians and academics), as well as the public and the media, that Pokryok in schools should be urgently 'eliminated' and 'eradicated' (MoE 2004; 2010). We thus have here an example of a 'polysemic' idea that becomes a coalition magnet (Schmidt 2017) bringing together diverse discursive communities, due to its ambiguous nature. Whilst the 'incompetent' education ministers and teachers were likely to take less punitive, more pedagogicallyappropriate measures to deal with bullying, the coalition of consensus over 'bullying' as a 'crime' led to punitive legislation enshrined in the Law on School Violence Prevention and Countermeasures and its revisions (MoE 2004, 2005, 2010).

These events coincided with the introduction of NPM in Korean public services, which travelled to Korea from the UK (Boo 2010). NPM introduced competition amongst the ministries of the government referred to above, as well as outsourcing of various government functions under the umbrella of 'small government' (Planning and Budget Office 1998, 2003). The punitive legislation to eradicate 'school violence' was, therefore, passed within the broader government narrative of 'effectiveness' and 'expertise', in a climate of distrust of the teaching profession. Government documentation on 'school violence' reflected the perception of teachers as non-experts. Terms such as 'expert' and 'professional' became associated with 'professional out-of-school institutions' and 'professional counsellors' rather than teachers (Joint Agency of the Related Ministries 2013).

The discursive framing of school 'bullying' as a 'crime' has thus enabled the outsourcing of the management of bullying to non-educational experts. This example differs from the typical outsourcing practices that rely on buying services from alternative, non-governmental providers and agencies. However, it follows the problem- 
solution logic discussed in the examples from the English and Hong Kong education systems below. Importantly, when 'Pokryok' in schools is regarded as a 'crime', attention is directed at punishing the perpetrator rather than restoring the relationship between the perpetrator and the victim and punishment takes precedence over improving the bully's behaviour. The focus thus shifts from educating students to assuring the fair treatment of bullying incidents. The reliance on legalistic rather than educational processes left in the hands of jurists, policemen and medical doctors has led to 'curtailed' teacher professionalism. As the anti-bullying laws turned classrooms into 'courtrooms', teachers have become alienated from the process of dealing with bullying incidents (Kim 2017). Although teachers were tasked with producing detailed reports on these incidents, they have been prevented under the School Violence Act from discussing these incidents with students or colleagues as 'classified information'. Paradoxically, therefore, whilst teachers gained detailed knowledge of bullying incidents, they were prevented from offering guidance to the students involved. These changes to the boundaries within which teachers used to work before the idea of 'bullying' was activated and institutionalised as 'school violence', led to a proliferation of role conflicts and psychological distress and, more recently, calls for amendments to legislation (Kim 2017).

\section{Academisation and 'multi-level' outsourcing in England}

Academisation in England can be viewed as 'multi-level outsourcing' which includes teaching, school governance and the whole system redesign. The problem-solution logic underpinning the programme for converting state schools to academies travelled to England from the USA, where it was deployed to open charter schools (Ravitch 2014). The English Academies Programme was initiated in 2000 by the Labour government, utilising the idea that taking a failing, local authority (LA) maintained school out of LA 
control and assigning it to a private sponsor would facilitate its improvement. Sponsorship played a double role, as a source of innovative ideas from the private sector and a source of financial support (initially, 10\% of the capital costs of new buildings or up to $£ 2$ million was required of sponsors). ${ }^{[3]}$ In addition to cognitive arguments about these benefits of sponsorship, the Academies Programme also activated power through ideas: through a 'vision' of education as a 'self-improving' system (PSR 2006) and a 'quasi market' (Maroy 2009), within the broader NPM narrative of the 'competition state' (Ball 2012a).

Academisation was accelerated after Labour lost power to the ConservativeLiberal Coalition (2010-2015) and from 2015, to the Conservatives. In addition to strong normative arguments which framed rapid improvement as a 'moral purpose' of education (DfE 2010, 28), academisation also required new legislative arrangements, whereby the governance of academies and academy chains resided with the multi-academy trust (MAT) as a new legal entity (NCTL 2014). Academy trusts do not have to abide by the national pay scales, national qualifications and working conditions for their teachers. Post 2010, schools graded as 'inadequate' were forced to become academies (Ball 2013). Far from bringing in financial support from the sponsor, academisation became a costly reform. According to the National Audit Office (NAO 2018), between 2010 and 2018, $£ 745.4 \mathrm{~m}$ was spent by the government on academy conversion costs alone. Sponsorship costs shifted from the sponsors to the taxpayer, through government grants paid to academy trusts (up to $£ 150,000$ per school). The focus on quantity rather than quality in academisation is reflected in the Department for Education (DfE) idea that 'educational excellence everywhere' can be realised in a system where 'every school is an academy' (DfE 2016, 53). As a result, at the level of education system, a 'school market' has emerged, funded by the taxpayer but 'open to new providers' (DfE 2010). 
Academisation is also an example of a more fundamental 'system redesign' which requires education professionals to 'engage in new logics of understanding change' (Rayner et al. 2018, 147). Rayner et al. (2018) locate academisation within the 'long-term neoliberal modernisation processes that create and exploit ruptures in public-service provision as a coherent system of school, curriculum and workforce management'. Outsourcing has been wheeled out to fill the gaps created by these ruptures, both outside of and as part of academisation. As in the example from Hong Kong discussed below, teacher workload problems were addressed through the 'workforce remodeling' policy that included employing teacher assistants to release teachers from tasks such as supporting struggling learners, marking and preparation of resources (Butt and Gunter 2007). In response to the problem of headteacher shortages, the requirement for headteachers to have a Qualified Teacher Status was lifted to involve a new cadre of noneducation professionals in the leadership of schools (Gunter and Forrester 2009).

At the level of communicative discourse used both by policymakers, the media and academy trustees, academisation focuses more on the business practices of 'restructuring', 'mergers', 'target setting' and 'performance management' than 'teaching and learning'. The following extract from an interview with the CEO of a MAT, is typical of such communicative discourse:

Jonathan Taylor, chief executive, said they were conscious of growing too big - and that they handpicked schools of various sizes, backgrounds and Ofsted ratings. "We are mindful of not growing too large too quickly..." (Cope 2017)

The discourses that frame education reform as a business project, with ideas about 'handpicking schools', 'growth' and 'investment' are so widespread that they drown counter-discourses circulated by the educational research community (Ball 2013; Gunter 
and McGinity 2014), organisations such as the Anti Academies Alliance, and media coverage of financial irregularities in some MATs (Adams 2016).

At the level of 'teaching and learning', academisation has also led to purchasing school curriculum from outside providers. For example, the Aurora Academies Trust has spent $£ 100,000$ a year on a patented 'Paragon curriculum' developed by the US private company Mosaica (Doward 2013). Aurora Academies Trust is run by Mosaica Education UK, a subsidiary of Mosaica Education Inc., an American EMO which runs schools in twelve US states, the United Arab Emirates and India. It promotes itself as a 'global leader in education reform'. Whilst the Aurora Academies Trust (n.d.) website refers to the 'acclaimed', 'interdisciplinary' Paragon curriculum 'that seamlessly weaves in from across all subjects' to prepare children 'to become the architects of tomorrow', the curriculum has been criticised by Ofsted inspectors for lacking 'local' focus (Doward 2013).

Rayner et al. $(2018,147)$ note that 'the post-politics turn in Western-style democracies' means that policy-based reforms may fail but 'the ideas underpinning such reforms remain in play'. Discursive institutionalist analysis illuminates how the 'multilevel' outsourcing underpinning academisation has advanced the 'fundamental system redesign'. Specifically, the institutionalisation of multiple forms of outsourcing introduced through academisation has been profoundly changing the fundamental institutional pillar on which public education had been built: teacher professionalism. The 'multi-level' outsourcing narrows the traditional conception of the 'teacher' as a 'source' of the 'whole' pedagogical process to that of a 'target-worker' accountable for the delivery of student performance outcomes. Appeals to 'excellence', 'aspirational targets' and 'improvement' alter the nature of obligation that teachers and school leaders have to students, particularly when student 'underachievement' endangers school performance 
targets (Bates 2016). At these multiple levels, academisation has legitimated a specific form of outsourcing, whereby education is still provided 'in-house', in the classroom, but teachers' work is increasingly managed by a cadre of non-educational leaders and CEOs of MATs. Once these new forms or working and 'principles of classification' (Lamont and Molnár 2002, 168) become normalised and internalised, they may become so deeply ingrained that it may take years to un-learn them.

\section{Outsourcing in an 'already outsourced' education system in Hong Kong}

The example of outsourcing of English language teaching in Hong Kong illustrates power in ideas that have become institutionalised, particularly the idea of a publicly-funded education system managed by non-government organisations. Hong Kong education can be referred to as an 'already outsourced' system because, due to its colonial history, it has been run, with government aid, by religious missions, charities and philanthropists from as early as the 1840s (Hung 2014; Choi 2018). Although gradual progress was made from the classic colonial laissez faire and minimal educational provision in the 1940s to the universalisation of primary and junior secondary schooling by the 1970s, the involvement of non-government sponsors has continued (Sweeting 1993). The introduction of compulsory education marked a change in coordinative discourse from quantity to quality. As explained by Cheng (2002), the 'quantitative era' in the development of education system in Hong Kong focused on the expansion of access to education, albeit at a low cost (below $3 \%$ of the GDP). ${ }^{[4]}$ The resulting 'cult of efficiency' rested on ultra-efficient use of resources (e.g. through the use of classrooms for teaching multiple cohorts of students) and low expenditure for the preparation of teachers. It was not until 1992 that the Education Commission Report recommended a fully graduate and fully trained teaching profession. However, introducing a compulsory education 
framework goes beyond the provision of school places by necessitating a focus on the quality of education to meet the expectations of parents and society at large. This marked the beginning of a 'qualitative era' in Hong Kong, with much attention focused on students' language competency (Cheng 2002).

In this context, the outsourcing of English language education has been framed through a mix of ideas pertaining to: efficiency (reminiscent of the 'quantitative' era), quality (in response to the 'qualitative turn') and improving students' learning and life chances. The latter links to government responsibility for providing quality education for all and the relative decline in standards following the introduction of compulsory education:

The practices that have been effective when educating the selected few were no longer valid in mass education... In lieu of major efforts to design new practices in order to maintain standards of some kind, there was a general decline of the standard. (Cheng 2002, 47)

Partly due to this sense of decline in standards and, importantly, due to the reunification of Hong Kong with China, sweeping reforms were introduced to improve education. These developments coincided with the spread of the NPM, which in Hong Kong conflated the 'cult of efficiency' and the 'qualitative turn' (Cheng 2002). The key players have been the Efficiency Unit (EU), a cross-department government unit established in the 1970s and the Education Bureau (EDB, equivalent of the Ministry of Education). Both units promote public-private partnership, with the EDB's remit also including the diffusion of the School-based Management reform. The normative arguments framing the activity of Efficiency Unit are reminiscent of the discourse of 'markets' in public education that have travelled across the globe: 
Public service markets are different from consumer markets... while consumers will pay more for better quality goods and services, the funding for public services is limited by government budget constraints, so service improvements often have to be achieved without additional funding. (EU 2008, 4) [our emphasis]

In promoting School-based Management, the EDB discourse utilises normative arguments about the 'principles of prudence and propriety' underlying the ability of schools to deploy funds as they deem appropriate:

Guided by general principles of prudence and propriety, the school will have flexibility over the deployment of its funds. (Advisory Committee on School-based Management, ACSM 2000, 6)

Cognitive arguments linking school autonomy to improved outcomes draw on research showing that autonomy improves student learning:

These include... autonomy for schools to select and manage staff, flexibility in the use of funds, greater involvement with the community... to improve learning. The research findings from the reform programmes are particularly noteworthy. (ACSM 2000, 5)

Emotional appeals have also been used, conflating what has been presented as a managerial issue (i.e. the outsourcing of teaching) with the commonly accepted ideals of citizenship:

Citizens' expectations of public services have risen. The collective culture of the nineteen-fifties when individuals accepted without question the public services available has been replaced by a market driven culture of citizens with varied lifestyles and needs. Today's citizens expect many of the same services from the public sector as the private sector - choice, convenience and the capacity for services to adapt over time to meet changing requirements. (EU 2008, 4) 
In this context, much of educational provision is funded by multiple government schemes aimed at helping schools to implement reform, addressing diverse student needs and reducing teacher workload. The system of government grants, available to all publiclyfunded schools, includes schemes such as: the Capacity Enhancement Grant; Senior Secondary Curriculum Support Grant; Learning Support Scheme targeted at specific groups of students (e.g. students with special educational needs, disadvantaged or gifted students) and Teacher Relief Grant. These schemes have been framed as a solution to the ongoing problem of excessive teacher workload that would allow schools to purchase services and curriculum packages from external organisations, thus allowing teachers to concentrate on 'the critical tasks in the education reform' (EDB 2017). With all these funds, schools in Hong Kong have acquired a new role of 'commissioners and monitors' in addition to the traditional role of 'deliverers' (Ball 2007, 5) of educational provision.

By drawing on these different sources of funding, schools can purchase English language curriculum packages, including the more traditional and ICT-integrated teaching and learning programmes, with content ranging from the basic level such as phonics to packages catering for advanced needs of 'elite' students such as debating. Whilst most Hong Kong schools have signed up for English learning programmes, both online and traditional, there are no policies regulating the quality of the outsourced educational provision (Choi 2018). Any registered company, home and international, can claim to be a provider and its services and programmes are monitored by the government only nominally through reporting, except for transparency in procurement. The quality assurance function has thus shifted onto schools, which need to monitor programme quality purchased through government grants. The resulting 'loophole' in the quality assurance of the outsourced programmes may be impacting negatively on the equity of 
educational opportunities. For example, despite the stated government objective of reducing the opportunity gap for students of lower socio-economic status, schools in affluent districts have greater access to language-rich resources for their students, whilst in the less affluent districts the focus is mainly on basic knowledge and skills (Choi 2018). This gap has been exacerbated by the existing division between schools where English rather than Chinese is the designated Medium of Instruction (even though schools may change the Medium of Instruction for part of their curriculum). Despite government intention of reducing teacher workload, the administrative and quality assurance functions seem to add to teacher workload and demand new skills and expertise to work with the new partners in public schooling. The upshot is that whilst the new expertise centres on quality assurance and administration, it is expertise in teaching that could directly impact on improvement in student learning. Thus, improving teacher education and recruiting teachers with relevant expertise could be both more cost-effective and more sustainable than buying services from private providers.

However, unlike in South Korea and England, where the approach to bullying in schools and academisation respectively continue to be resisted, the involvement of private companies in education in Hong Kong appears to be taken as the norm. Pre-emptying any possible contestation of outsourcing in what is an 'already outsourced' system in Hong Kong is predicated on continuing along the same trajectory, because:

It is the best way to integrate a host of changes which are already in train and which are intended to raise the quality of education for every student. (ACSM 2000, i) [our emphasis]

The absence of public contestation is partly predicated on the long history and the ensuing institutionalisation of outsourcing and partly on the unique approach to education reform 
in Hong Kong which seeks to minimise conflicts and tensions. This approach has been described as 'conservative' and 'incremental', reflecting a context where 'institutions and powerful groups within the system enjoy sufficient power to exercise vetoes over policy and to frustrate the intentions of the policymakers' (Scott 2005, 34). The stance of the post-colonial government toward the education provision has been minimal intervention. When radical changes are necessary, the government chooses to create ambiguity, as a 'tried and tested' strategy for reducing conflict (Choi and Walker 2018). Radical changes are therefore 'couched in terms (for example, quality teaching, learning to learn, generic skills) that require no real decisions or choices to be made in terms of ideology or of resources', rather than by openly trying to gain the hard-to-earn consensus through 'the ballot box, a free press, and a vigorous civil society' (Morris and Scott 2005, 88, 95).

\section{Discussion: outsourcing solutions and New Public Management}

The examples from South Korea, England and Hong Kong illustrate how the discursive framing of outsourcing shows striking similarities, both in terms of its underpinning logic and its negative consequences. In each example, outsourcing has been discursively framed as an effective solution to educational problems ostensibly beyond the competence or capability of teachers. In South Korea, the discourse on bullying coalesced around the belief that neither the Ministry of Education nor teachers in schools were competent enough to effectively deal with bullying. In England, the discourse of marketisation engendered a consensus amongst key discursive players to support converting schools to academies, sponsored by non-educational experts as the key drivers of improvement. In Hong Kong, escalating teacher workloads, combined with the imperative of addressing diverse student needs, have been framed as beyond the capability of teachers. An assumption underlying all three examples is that solutions to 
educational problems are to be found outside rather than within schools. This assumption, however, highlights the limits to outsourcing as a panacea for diverse educational problems. Whilst outsourcing may ameliorate some of the problematic 'symptoms' in the short term, it is investing in teacher capability and competency to address the very sources of educational problems, from within, that may be a more effective long-term solution.

A closer scrutiny of the arguments for outsourcing in South Korea, England and Hong Kong reveals why, rather than providing solutions, outsourcing generated several new problems. Ironically, the transference of responsibility for managing bullying in schools to outside experts in South Korea has been rooted in the 'polysemic' ambiguity of the term Pokryok, with its connotations of 'crime' leading to punitive rather than educational responses. In England, the questionable assumption that school improvement can be triggered by redesigning the education system as a 'school market' has led to the high cost to the taxpayer of academy conversion, whilst the educational benefits of academisation are increasingly contested. In an established outsourced education system in Hong Kong, research on the effectiveness of outsourcing in improving education raised concerns about quality and equity. The issues of quality and equity are also writ large in England, where the quality of education varies amongst different Multi Academy Trusts and successful trusts tend to 'handpick' schools on the basis of size, background and Ofsted ratings rather than equitable provision. Whereas professionals working within a state education system are accountable to the state for the quality and equity of education they deliver, providers of outsourced education services enter contracts under transaction cost economics, with cost often taking priority over quality and equity (Norris and Kushner 2007).

At the heart of the idea of outsourcing is New Public Management (NPM) and its underlying assumption that public services can be improved through the application of 
the market mechanism of competition, public choice theory, business values and microeconomics (Norris and Kushner 2007). Consequently, the government approach to reforming public services in England has been predicated on managerialist solutions such as: 'building public services around the user'; 'breaking down silos'; 'culture change away from traditional command and control models of leadership' (Sandford 2016, 8) and a 'level playing field for all independent providers' (HM Government 2011, 39). Similarly, the model of a 'joined-up government' in Hong Kong has sought 'new forms of collaboration with non-government or civil society organisations' that transcend "traditional structures and "silos" in order to "match the efficiency, coordination and convenience offered by the best in the private business world' (Efficiency Unit 2009, 27). The idea of public-private collaboration has also been presented as a key strategy for a 'market-based government that supports private businesses' in South Korea (Special Committee 2001, 7). The ubiquity of outsourcing can thus be seen as partly a result of the 'managerial turn' by the governments of countries that are influenced by NPM. At face value, the ideas about 'breaking down silos', 'new forms of collaboration with nongovernment and civil society organisations' and 'efficiency, coordination and convenience offered by the best in the private business world' seem to have an appealing logic.

However, for some time now, private sector organisations have themselves struggled with a loss of focus on quality as a key source of professionalism (Khurana 2007). Since the 1970s, this focus has been increasingly replaced with the managerialist logics of cost-cutting and efficiency and, ultimately, the market logics of competition and profit maximisation. Efficiency and profit are not sufficient for establishing social legitimacy and when professions lose their 'higher aims' and, therefore, their legitimacy, 
'the times are ripe for their reinvention' (Khurana 2007, 383). It is a renewal of teacher professionalism that provides the focus of the concluding section.

\section{Conclusion: a renewal of teacher professionalism}

This paper has deployed discursive institutionalism as an analytical framework for tracing the processes of activation, circulation and institutionalisation of outsourcing as they may play out in diverse national contexts. The examples from South Korea, England and Hong Kong illustrate how the outsourcing of education services to third party providers makes education vulnerable to the loss of traditional institutional pillars of teacher professionalism: knowledge of pedagogy and curriculum design, autonomy and a 'calling' to public service. Importantly, outsourcing educational problems diminishes the significance of teachers' own sources of expertise, thus disrupting the knowledge base, history and available resources necessary for improving the school as an institution in its own right. In each example discussed in this paper, outsource-based reform introduced a demand on teachers to develop new ways of working to 'fit' with the redesigned system rather than get on with the task of solving the problem at hand. The sources of teacher professionalism did not fare well in comparison with those of non-educational experts deemed to be 'more competent' to deal with school bullying in South Korea. Academisation in England often frames school leadership and governance around restructuring, investment, growth and mergers rather than 'teaching and learning', with teachers' work managed by a new cadre of non-educational leaders and multi-academy trusts. The example from Hong Kong reveals an even more far-reaching shift in the balance of teachers' work, from teaching to grant application, administration and quality assurance. 
Whilst the main focus of our paper has been on the outsourcing of elements of 'teaching and learning', the broader processes of 'businessification' of government under New Public Management suggest that policymakers who have internalised the discourse on outsourcing may struggle to make decisions on the basis of alternative logics. It is, therefore, important to remain alert to events that provide grounds for re-evaluating outsource-based reform and renewing the educational mission of schools. Such 'windows of opportunity' (Kingdon 1984) open when research findings reveal adverse consequences of outsourcing (Choi 2018; Rivera 2018; Wekullo 2017) and when governments themselves abandon unworkable outsource-based reforms. An important recent example is the New Zealand government's plan to put an end to the previous government's charter school 'experiment' (Vance 2018).

On the discursive institutionalist view, however, it is the teachers and school leaders who need to recognise themselves as 'ideational leaders', as sources of knowledge, quality and improvement in education with power over and through ideas, rather than 'rhetorical leaders' who simply repeat the policy rhetoric to enact reform. Much, therefore, depends on teacher and leadership education, which needs to focus on the sources of professional knowledge within rather than outside of educational practice. Enabling teachers to develop knowledge as a resource for their professionalism needs to go beyond 'teaching and learning' to embrace 'knowledge politics': an understanding of the political processes at play in the selection, production, mobilisation and dissemination of what counts as 'professional knowledge' (Seddon et al. 2013, 15). As Seddon et al. (2013) explain, the way teachers engage these wider 'knowledge politics' affects their capacity to negotiate their own values as legitimate educational projects. Since both policymakers and the public are influenced by institutions such as the market, the professions and social hierarchies, educational projects need to emphasise the role of 
these institutions in defining social and educational values. At a time when outsourcebased education reform and its logics of cost-cutting and efficiency are turning out to be problematic, there is a need to redefine education reform in terms of value rather than cost. It is an ongoing evaluation of outsourcing and other 'travelling' education reforms, by teachers engaged with 'knowledge politics', that may be at the source of the muchneeded renewal of educational professionalism.

\section{Notes}

[1] 'Outsourcing' is a broad umbrella term for arrangements that include 'public-private partnerships', 'private finance initiatives' or 'contracting out' the delivery of educational services (Rivera 2018).

[2] As Wahlström and Sundberg (2018) point out, discursive institutionalism has not yet been fully utilised in educational research, even though it offers a multifaceted set of concepts for exploring policy borrowing at transnational, national and local levels.

[3] The arrangements for sponsorship were later changed, allowing sponsors to establish an endowment fund rather than contribute to capital costs. In 2007 the sponsorship requirement was abolished for high-performing schools (Long 2015).

[4] By comparison, expenditure on education in Hong Kong rose to $7.6 \%$ of the GDP between 1980 and 1990 (Tilak 2002).

\section{References}

Adams, R. 2016. "Lauded academy chain to be stripped of schools after finances inquiry." The Guardian (28 March). https://www.theguardian.com/education/2016/mar/28/perry-beeches-academychain-stripped-schools-critical-finance-report.

Adams, O.L., Guarino, A.J., Robichaux, R.R., and T.L. Edwards. 2004. "A comparison of outsourcing in higher education, 1998-99 and 2003-04." Journal of Educational Research \& Policy Studies 4(2): 90-110. 
ACSM (Advisory Committee on School-based Management). 2000. Transforming schools into dynamic and accountable professional learning communities: Schoolbased management consultation document. Hong Kong: Advisory Committee on School-based Management.

Aurora Academies Trust (n.d.) Our Approach: Making a World of Difference. http://auroraacademies.org/our-approach/.

Ball, S.J. 2007. Education Plc: Understanding Private Sector Participation in Public Sector Education. London: Routledge.

Ball, S.J. 2012a. "The reluctant state and the beginning of the end of state education." Journal of Education Policy (44)2: 89-103.

Ball, S.J. 2012b. Global Education Inc: New Policy Networks and the Neo-Liberal Imaginary. London: Routledge.

Ball, S.J. 2013. Education, justice and democracy: The struggle over ignorance and opportunity. London: Centre for Labour and Social Studies.

Ball, S.J., and Junemann, C. 2012. Networks, New Governance and Education. Bristol: The Policy Press.

Bates, A. 2016. "Reculturing schools in England: how 'cult' values in education policy discourse influence the construction of practitioner identities and work orientations." Critical Studies in Education 57(2): 191-208.

Boo, H.-W. 2010. 'Korea's Experience with NPM-Based Reform: Applying the Policy Fashion Concept." The Korean Journal of Policy Studies 25(1): 19-33.

Burch, P. 2009. Hidden Markets: The new education privatization. New York and London: Routledge.

Butt, G. and H.M. Gunter. 2007. Modernizing Schools: People, Learning and Organization. London: Continuum.

Cheng, K.-M. 2002. “The Quest for Quality Education: The Quality Assurance Movement in Hong Kong." In Globalization and Education: The Quest for Quality Education in Hong Kong, edited by Mok, J.K.H. and D.K.K. Chan, 41-66. Hong Kong: Hong Kong University Press.

Choi, T.-H. 2018. "English education in partnership with third parties: A case of equity in Hong Kong." In The Asian EFL classroom: Issues, challenges and future expectations, edited by Kweon, S.-O. and B. Spolsky, 169-188. Abingdon, Oxon: Routledge. 
Choi, T.-H. and A.D. Walker. 2018. "A heuristic model for tailoring teacher development to educational reforms: Focusing on ambiguity and conflict generation." Teaching and Teacher Education (74): 72-84.

Chung, J. 1996. “The Primary Responsibility for School Violence”. In Dong-A Ilbo.

Cope, L. 2017. "Growing Norfolk academy trust marks 11 schools in 18 months." Eastern Daily Press (8 December). http://www.edp24.co.uk/news/education/academy-trust-founded-at-wymondhamcollege-grows-to-11-schools-in-18-months-1-5313154.

Cuban, L. 2012. Reforming Businesses, Reforming Schools: Outsourcing as a Fad. https://arrycuban.wordpress.com/2012/12/.

DfE (Department for Education). 2010. The importance of teaching: The schools White Paper 2010. London: Crown Copyright.

DfE (Department for Education). 2016. Educational Excellence Everywhere. Schools White Paper 2016. London: Crown Copyright.

Dong-A Ilbo. 1995. School Violence, is it leaving as it is? (22 November).

Doward, J. 2013. “Sussex academy pays $£ 100,000$ to use 'patented' US school curriculum." The Observer (18 May).

https://www.theguardian.com/education/2013/may/18/academy-pays-for-uscurriculum.

Education Bureau (EDB). 2017. Reference Materials on Capacity Enhancement Grant. http://www.edb.gov.hk/en/sch-admin/fin-management/subsidy-info/ref-capacityenhancement-grant/index.html.

Efficiency Unit (EU). 2008. Customer service in the delivery of public services: International experience. Hong Kong: Efficiency Unit.

Efficiency Unit. 2009. Joined-Up Government. Hong Kong: Central Government Offices.

Ellis, V., Maguire, M., Trippestad, T.A., Liu, Y., Yang, X. and K. Zeichner. 2016. "Teaching other people's children, elsewhere, for a while: the rhetoric of a travelling educational reform." Journal of Education Policy 31(1): 60-80.

Fischer, F. and H. Gottweis. (Eds.). 2012. The Argumentative Turn Revisited: Public policy as communicative practice. Durham and London: Duke University Press.

Gunter, H.M. and G. Forrester. 2009. "School leadership and education policy-making in England." Policy Studies 30(5): 495-511. 
Gunter, H.M. and R. McGinity. 2014. "The Politics of the Academies Programme: Natality and Pluralism in Education Policy-making." Research Papers in Education 29(3): 300-314.

Grace, G. 2014. "Professions, sacred and profane: Reflections upon the changing nature of professionalism." In Knowledge, Expertise and the Professions, edited by Young, M. and J. Muller, 18-30. London and New York: Routledge.

Hankyoreh. 1997. "Causes and Measures of Excessive violence at schools." (7 October).

HM Government. 2011. Open Public Services White Paper. London: The Stationery Office.

Hood, C. 1995. "The "New Public Management"' in the 1980s: Variations on a theme." Accounting Organizations and Society 20(2/3): 93-109.

Hung, S.C.F. 2014. "Public education establishment in the earliest colonial period of Hong Kong: A historical re-constructivist explanation." Journal of Arts and Humanities 3(8): 90-103.

Hursh, D. 2016. The End of Public Schools: The Corporate Reform Agenda to Privatize Education. New York: Routledge.

Hursh, D. 2017. "The end of public schools? The corporate reform agenda to privatize education." Policy Futures in Education 15(3): 389-399.

Joint Agency of the Related Ministries. 2013. The Countermeasures for School Violence. Soul: Joint Agency of the Related Ministries.

Kang, J. 2012. A study of a restorative justice model as a means to resolve of school violence. http://www.ksste.or.kr/bbs/board.php?bo table=ksste04 01\&wr id=38\&pag $\underline{\mathrm{e}=3}$.

Khurana, R. 2007. From Higher Aims to Hired Hands: The Social Transformation of American Business Schools and the Unfulfilled Promise of Management as a Profession. Princeton and Oxford: Princeton University Press.

Kim, Y. 2017. “법화사회의 진전과 학교 생활세계의 변용” [“The legalization of educational administration and the change of teachers' Lebensweld"']. Korean Journal of Educational Administration (35)1: 87-112.

Kingdon, J. 1984. Agendas, Alternatives and Public Policies. New York: Longman. Kyunghyang Shinmun. 1997. "The President directs cabinet to stamp out school violence" (9 July). 
Lambert, M.T. 2014. Privatization and the public good: Public universities in the balance. Cambridge, MA: Harvard Education Press.

Lamont, M. and Molnár, V. 2002. "The Study of Boundaries Across the Social Sciences." Annual Review of Sociology 28:167-95.

Lane, J.E. 2000. New public management. London: Routledge.

Lingard, B. and Sellar, S. 2013. "Globalization, edu-business and network governance: the policy sociology of Stephen J. Ball and rethinking education policy analysis." London Review of Education 11(3): 265-280.

Long, R. 2015. Academies under the Labour Government. London: House of Commons Library. http://dera.ioe.ac.uk/22717/1/SN05544.pdf.

Mahony, P., Menter, I. and I. Hextall. 2004. "Building Dams in Jordan, assessing teachers in England: a case study in edu-business." Globalisation, Societies and Education 2(2): 277-96.

Maroy, C. 2009. "Convergences and hybridization of educational policies around "postbureaucratic' models of regulation." Compare 39(1): 71-84.

MoE (Ministry of Education). 1995. The Cross-Ministry Policy Measures for School Violence. Soul: Ministry of Education.

MoE. 2004. The $1^{\text {st }}$ Basic Plan for Prevention and Measures for School Violence (20152019). Soul: Ministry of Education.

MoE. 2005. The $2^{\text {nd }}$ Basic Plan for Prevention and Measures for School Violence (2005-2009). Soul: Ministry of Education.

MoE. 2010. The $3^{\text {rd }}$ Basic Plan for Prevention and Measures for School Violence (2010-2014) (in Korean). Soul: Ministry of Education.

Morris, P. and I. Scott. 2005. "Education reform and policy implementation in Hong Kong." In Education reform and the quest for excellence: The Hong Kong story, edited by Ho, L.S and P. Morris, 83-97. Hong Kong: Hong Kong University Press.

National Audit Office (NAO). 2018. Converting maintained schools to academies. https://www.nao.org.uk/report/converting-maintained-schools-to-academies/

NCTL (National College for Teaching and Leadership). 2014. Governance in MultiAcademy Trusts. Nottingham: NCTL.

Norris, N. and S. Kushner. 2007. "The New Public Management and Evaluation.” In Dilemmas of Engagement: Evaluation and the New Public Management, edited by Kushner, S. and N. Norris, 1-16. Bingley: Emerald Group Publishing Limited. 
Pilling, D. 2017. "Liberia is outsourcing education. Can it work?" Financial Times (21 April). https://www.ft.com/content/291b7fca-2487-11e7-a34a-538b4cb30025.

Planning and Budget Office. 1998. The Budget Programming Guideline of 1999. Soul: Planning and Budget Office.

Planning and Budget Office. 2003. The White Paper on the Public Administration Reform of the Kim Daejung Government. Soul: Planning and Budget Office.

Powell, W.W. and P.J. DiMaggio. (Eds.). 1983. The New Institutionalism in Organizational Analysis. Chicago: University of Chicago Press.

PSR (Public Service Reform team). 2006. The UK government's approach to public service reform. London: Crown Copyright.

Ravitch, D. 2014. Reign of Error: The Hoax of the Privatization Movement and the Danger to America's Public Schools. New York: Vintage Books.

Rivera, M.D. 2018. "Paying for financial expertise: privatization policies and shifting state responsibilities in the school facilities industry." Journal of Education Policy 33(5): 704-737.

Rayner, S.M., Courtney, S.J. and H.M. Gunter. 2018. "Theorising systemic change: learning from the academisation project in England." Journal of Education Policy 33(1): 143-162.

Sandford, M. 2016. Briefing Paper Number 05950: Local government: alternative models of service delivery. House of Commons Library.

Schmidt, V.A. 2008. "Discursive institutionalism: the explanatory power of ideas and discourse." Annual Review of Political Science 11: 303-26.

Schmidt, V.A. 2010. "Taking ideas and discourse seriously: explaining change through discursive institutionalism as the fourth new institutionalism." European Political Science Review 2(1): 1-25.

Schmidt, V.A. 2017. "Britain-out and Trump-in: a discursive institutionalist analysis of the British referendum on the EU and the US presidential election." Review of International Political Economy 24(2): 248-269.

Scott, I. 2005. "Education policymaking in a disarticulated system." In Education reform and the quest for excellence: The Hong Kong story, edited by Ho, J.S. and P. Morris, 23-36. Hong Kong: Hong Kong University Press.

Seddon, T., Ozga, J. and J.S. Levin. 2013. “Global Transitions and Teacher Professionalism." In World Yearbook of Education 2013. Educators, Professionalism and Politics: Global Transitions, National Spaces and 
Professional Projects, edited by Seddon, T. and J.S. Levin, 3-24. London: Routledge.

Special Committee. 2001. Korea's e-Government: Completion of e-Government Framework. Republic of Korea: Special Committee for e-Government.

Sweeting, A. 1993. A Phoenix Transformed. Hong Kong: Oxford University Press.

Tilak, J.B.G. 2002. Building Human Capital in East Asia: What Others Can Learn. Washington DC: The International Bank for Reconstruction and Development/The World Bank.

Vance, A. 2018. "Government unveils law to scrap charter schools but some can stay of 'case by case' basis.” News Now (8 February). https://www.tvnz.co.nz/onenews/new-zealand/government-unveils-law-scrap-charter-schools-but-some-canstay-case-basis.

Wahlström, N. and D. Sundberg. 2018. "Discursive institutionalism: towards a framework for analysing the relation between policy and curriculum." Journal of Education Policy (33(1): 163-183.

Wekullo, C.S. 2017. "Outsourcing in higher education: the known and unknown about the practice." Journal of Higher Education Policy and Management 39(4): 453468.

Williams, Z. 2012. The Shadow State: A report about outsourcing of public services. Social Enterprise U. 